\title{
Г.О. КАЗАРІНОВА
}

Інститут ботаніки імені М.Г. Холодного НАН України

вул. Терещенківська, 2, м. Київ, 01601, Україна

Харківський національний університет імені В.Н. Каразіна

пл. Свободи, 4, м. Харків, 61022, Україна

kazarinovaann@mail.ru

\section{СИНГЕНЕТИЧНІ ЗМІНИ ВИЩОЇ ВОДНОЇ РОСЛИННОСТІ ДОЛИНИ р. СІВЕРСЬКИЙ ДОНЕЦЬ}

Ключові слова: вища водна рослинність, динаміка, сингенез, сукиесійні ряди, Сіверський Донець

\section{Вступ}

Значний антропогенний тиск на водні екосистеми та недостатнє водозабезпечення досліджуваного регіону зумовлюють актуальність усебічного вивчення змін вищої водної рослинності. Заростання (сингенетичні зміни) є пусковим механізмом для майбутніх сукцесійних процесів, які визначають подальший розвиток водних екосистем.

Сингенетичні сукцесії досить характерні для водойм, де відбувається постійне формування нових мілководних ділянок [3]. Це - початковий процес утворення рослинного покриву, який розвивається на цій території. В подальшому через наявність донних відкладів змінюються умови місцезростань, а отже, на розвитку рослинності все більше позначаються ендоекогенетичні зміни, що переважають на стадії формування поясів рослинності.

Сингенетичні зміни вищої водної рослинності долини р. Сіверський Донець на сьогодні вивчені недостатньо. Результати досліджень процесів заростання Лиманської системи озер і боліт у 1920-1930-х і 1950-х роках наводяться в роботах Є.М. Лавренка та М.Г. Алексєєнко [2, 6].

Мета нашої роботи - аналіз сингенетичних змін вищої водної рослинності (ВВР) водойм досліджуваної території. Для цього потрібно було виявити сукцесійні ряди ВВР у різних типах водойм із вираженою течією (русло Сіверського Дінця, канали), з відсутньою або незначною течією (озера, стави, водосховища), з різними глибинами, на піщаних або мулистих грунтах.

\section{Матеріали та методи дослідження}

Дослідження процесів заростання проводилися на ключових ділянках шляхом встановлення сукцесійних (часових) зв'язків на основі результатів вивчення просторових (екологічних і фітоценотичних) рядів угруповань протягом 2011-2013 pp. [1]. (с) Г.О. КАЗАРІНОВА, 2014

ISSN 0372-4123. Укр. ботан. журн., 2014, m. 71, № 4
У цій статті охарактеризовано процеси заростання, властиві екотопам, що приурочені до відмінних за походженням і типом гідрологічних процесів водойм і різних типів грунтів: прибережні ділянки русла Сіверського Дінця з різною глибиною, наявністю течії, рельєфом дна, з піщаними, піщано-мулистими та мулистими донними відкладами; мілководні ділянки русла й мілководдя заток річки з постійним рівнем води та відмінними типами донних відкладів; ділянки ложа малих каналів при TEC, які є слабопроточними водотоками з товщею води 50-250 см і вирізняються особливостями термічного режиму та мулистими донними відкладами; заплавні водойми (озера, стариці), що мають глибину до 250 см, а також характеризуються відсутністю течії і наявністю мулистих донних відкладів; озера Лиманської системи, де заростання відзначається на мілководних, захищених ділянках, у затоках завглибшки до 100-150 см із піщано-мулистими та торф'янисто-мулистими донними відкладами (озера Лиман, Чайка, Комишувате, Борове); солонуваті замкнуті водойми зі слабким поверхневим і значним коливанням рівня води протягом вегетаційного періоду, піщано-мулистими донними відкладами й товщею води 20-50 cм (озера урочища «Горіла долина»); прибережні ділянки водосховищ (Печенізьке, Бєлгородське) і ставків із товщею води до $50 \mathrm{~cm}$, піщаними та піщано-мулистими донними відкладами і значним коливанням рівня води протягом вегетаційного періоду, мілководні, захищені від вітру та хвиль, ділянки водосховищ із постійним рівнем води, піщано-мулистими й мулистими донними відкладами, товщею води до $200 \mathrm{~cm}$.

\section{Результати досліджень}

Сингенетичні зміни розпочинаються з появи перших рослин - піонерів заростання, а далі відбувається їхнє розмноження й розселення, форму- 
вання заростей, до яких проникають інші види, що згодом призводить до утворення поясів водної рослинності. При цьому угруповання, що формуються, проходять три фази - піонерну, груповозаростеву та дифузну [5, 7]. Сингенетичні зміни поділяються на первинні та вторинні. Первинний сингенез характерний для алювіальних ділянок русла річки та мілководдя новостворених водойм. Вторинний - спостерігається на ділянках ставків, прибережних ділянках русла Сіверського Дінця, де починається відновлення ВВР на порушених екотопах унаслідок осушення, викошування повітряно-водних рослин (стави) та намивання грунту (ділянки русла в гирлі р. Сіверський Донець). Перебіг сукцесій відбувається внаслідок послідовних змін груп видів із різними еколого-ценотичними стратегіями: від типових експлерентів (Alisma plantago-aquatica L., Oenanthe aquatica (L.) Poir., Cyperus glomeratus L., Alopecurus geniculatus L. та ін.) до ценозотвірних віолентів і патієнтів (Phragmites australis (Cav.) Trin. ex Steud., Typha angustifolia L., Myriophyllum verticillatum L., Nuphar lutea (L.) Sm. тощо). Зі збільшенням шару донних відкладів, формуванням і ускладненням структури рослинного покриву сингенез за 4-5 років змінюється ендоекогенезом, який є результатом перетворення середовища існування самою рослинністю [3].

Заростання русла річки та каналів має певні особливості, які пов'язані зі швидкістю течіі, рельєфом дна, глибиною (товщею води), складом донних відкладів і впливом людини.

Швидкість течії русла Сіверського Дінця - 0,50,8 м/с, каналів - 0,2-0,3 м/с, русло має значну кількість заток, багато перекатів із товщею води 1-2 м, піщаними, піщано-мулистими та мулистими донними відкладами.

Сприятливіші умови для заростання ВВР створюються на мілководних захищених ділянках русла річки з пологою літораллю, глибина якої до 200 см, iз піщано-мулистими або мулистими донними відкладами. Визначальними факторами в процесах заростання русла річки та каналів досліджуваного регіону є гідрологічні особливості (повільна течія, формування алювіальних наносів) й антропогенний вплив (значна кількість гідроспоруд, скидання стічних вод підприємствами, ТЕС).

Заростання алювіальних ділянок русла Сіверського Дінця в середній течії з товщею води 20-50 см та піщаними донними відкладами починається 3 появи поодиноких занурених видів
Potamogeton perfoliatus L., P. pectinatus L., Vallisneria spiralis L., які формують мозаїчно розміщені куртини (околиці м. Зміїв, Харківська обл.). На 2-3-й рік у заростанні беруть участь Myriophyllum spicatum L., M. verticillatum, Sagittaria sagittifolia L., Glyceria maxima (Hartm.) Holmb., Scirpus lacustris L. На етапі дифузних угруповань на 4-5-й рік домінують Typha angustifolia, T. latifolia L. i Phragmites australis. Заростання алювіальних ділянок русла у верхів"ї Сіверського Дінця (околиці с. Біломістне, Бєлгородський р-н, Бєлгородська обл.), де глибина води до 50 см і мулисто-піщані грунти, починається $з$ появи таких вільноплаваючих рослин, як Lemna minor L., Spirodela polyrrhiza (L.) Schleid., або із заселення повітряно-водними видами Alisma plantago-aquatica, Sagittaria sagittifolia, Catabrosa aquatica (L.) Р. Beauv. Через 2-3 роки ці види вже заселяють значну частину русла, в заростанні також беруть участь Glyceria arundinacea Kunth, Phalaroides arundinacea (L.) Rausch., Typha latifolia i Phragmites australis. Зауважимо, що заростання ділянок із товщею води понад 50 см, наявністю течії до 0,8 м/с і піщаними донними відкладами відбувається завдяки формуванню заростей Potamogeton perfoliatus, $P$. pectinatus i Ceratophyllum demersum L. Через 2-3 роки на етапі групово-заростевої фази помітну роль у заростанні починають відігравати Sagittaria sagittifolia f. vallisneriifolia, Sparganium erectum L., на 4-5-й рік на етапі дифузних угруповань - Scirpus lacustris і Typha latifolia. У заростанні ділянок русла річки з товщею води понад $100 \mathrm{~cm}$, незначною течією $(0,2-0,3 \mathrm{~m} / \mathrm{c})$ і мулистими донними відкладами беруть участь такі справжні водні види, як Elodea canadensis Michx., Najas marina L., Potamogeton natans L., Nuphar lutea. Ці види розміщуються мозаїчно. У зв'язку з продукуванням органіки, збільшенням донних відкладів, а отже, зменшенням глибини, посилюється роль повітряно-водних видів - Sagittaria sagittifolia, Sparganium erectum, Glyceria arundinacea, які розширюють площі заростання на етапі дифузних угруповань (околиці с. Огірцеве, Вовчанський р-н, Харківська обл.). Алювіальні ділянки русла Сіверського Дінця, які розташовуються біля гирла основних приток річки, характеризуються глибиною 20-50 см, мулистими грунтами та незначною течією $(0,2-$ 0,3 м/с) або іiї відсутністю. На цих ділянках заростання починається з появи Ceratophyllum demersum, Lemna minor, Spirodela polyrrhiza, Salvinia natans (L.) All., Hydrocharis morsus-ranae L. На етапі утворення

ISSN 0372-4123. Ukr. Bot. J., 2014, 71(4) 
групово-заростевих угруповань посилюється роль Utricularia vulgaris L. i Stratiotes aloides L.

Русло Сіверського Дінця поблизу мостів утворює рукави, які характеризуються наявністю алювіальних ділянок із товщею води до 50 см і пішано-мулистими грунтами. Такі ділянки заростають повітряно-водними видами - Alisma plantagoaquatica, Persicaria hydropiper (L.) Delarbre, Mentha aquatica L., Typha latifolia, Phragmites australis. Через 2-3 роки ці види заселяють мілководдя вздовж берегів, серед яких розвиваються вільноплаваючі рослини Lemna minor, Spirodela polyrrhiza i Salvinia natans (околиці сіл Черкаський Бішкин і Червоний Донець; Балакліївський р-н, Харківська обл.).

Отже, узагальнена схема заростання русла з піщаними грунтами має такий вигляд:

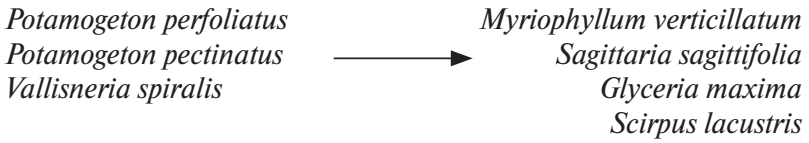

Для ділянок русла з мулисто-піщаними донними відкладами:

Elodea canadensis

Najas marina

Sagittaria sagittifolia

Potamogeton natans

Nuphar lutea

Для ділянок русла з мулистими грунтами:

Lemna minor

Spirodela polyrrhiza

Hydrocharis morsus-ranae

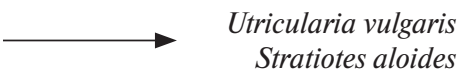

Ceratophyllum demersum

Для русла Сіверського Дінця у верхній течії характерна схема за участю Catabrosa aquatica, Phalaroides arundinacea:

Lemna minor

Spirodela polyrrhiza або

Alisma plantago-aquatica

Archangelica officinalis

Sagittaria sagittifolia

Catabrosa aquatica

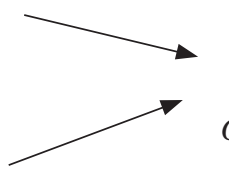

Lemna minor

Sagittaria sagittifolia

Catabrosa aquatica Glyceria arundinacea

У затоках річки, де вплив руслових процесів мінімальний, 3 мулисто-піщаними та мулистими грунтами й товщею води понад 50 см заростання починається з появи справжніх водних видів Potamogeton perfoliatus, $P$. pectinatus, $P$. compressus L., P. trichoides Cham. et Schlecht., Myriophyllum verticillatum, Nuphar lutea, Ceratophyllum demersum, які на початкових етапах заселення займають най- більші площі. На 3-й рік, унаслідок накопичення органічних речовин і обміління, основними компонентами заростання стають повітряно-водні види Sagittaria sagittifolia, Sparganium erectum, Acorus calamus L. i Glyceria maxima.

Узагальнену схему заростання заток річки з мулисто-піщаними та мулистими грунтами можна зобразити так:

Potamogeton perfoliatus Ceratophyllum demersum Potamogeton pectinatus Myriophyllum verticillatum Ceratophyllum demersum Potamogeton compressus Potamogeton trichoides Nuphar lutea

Ступінь заростання малих каналів, які використовуються теплоелектростанціями, розміщеними на досліджуваній території, становить $80 \%$. Заростання ділянок із товщею води $10-50 \mathrm{~cm}$, піщано-мулистими та мулистими донними відкладами починається з появи занурених водних рослин Potamogeton perfoliatus, Vallisneria spiralis, Elodea canadensis, Ceratophyllum demersum. Через 2-3 роки ці види вже заселяють значну частину каналу. На цьому етапі заростання посилюється роль вільноплаваючих рослин Lemna minor, Spirodela polyrrhiza, Lemna trisulca L., Hydrocharis morsus-ranae. У зв'язку з інвазією Pistia stratiotes L. у Сіверському Дінці цей вид відіграє домінуючу роль у заростанні мілководних ділянок і прибережних смуг каналу (канал ТЕЦ-2 «Есхар», Чугуївський р-н, Харківська обл.). Рослини закріплюються на куртинах Ceratophyllum demersum, Vallisneria spiralis i Potamogeton perfoliatus, утворюючи щільні скупчення з участю Lemna minor i Spirodela polyrrhiza. Внаслідок особливостей терморежиму вегетація в таких водотоках може тривати і в зимовий період (температура води в грудні-січні становить тут $+14-18^{\circ} \mathrm{C}$ ), що сприяє подальшому покриттю мілководь Pistia stratiotes. Заростання ділянок каналів із товщею води $0-50 \mathrm{~cm}$ i піщаними донними відкладами починається із заселення повітряно-водними видами Mentha aquatica, Scirpus lacustris, Typha latifolia, Phragmites australis, які на етапі дифузних угруповань збільшують площі (канал Зміївської ТЕС, Балакліївський p-н, Харківська обл.). Загалом зафіксовано прискорення процесів сингенезу (2-3 роки) в каналах і на ділянках біля скидання вод, підігрітих ТЕС.

Узагальнена схема заростання малих каналів досліджуваної території:

Potamogeton perfoliatus

Elodea canadensis

Vallisneria spiralis

Ceratophyllum demersum
Lemna minor Spirodela polyrrhiza Hydrocharis morsus-ranae Pistia stratiotes 
Характер заростання заплавних евтрофних водойм і його інтенсивність залежить від рівня та тривалості весняних паводків, глибини водойми, субстратів. Заростання стариць площею до 10 га, з товщею води 50-100 см, піщаними та піщано-мулистими грунтами починається з появи справжніх водних видів, зокрема Ceratophyllum demersum, Potamogeton perfoliatus, Elodea canadensis, які займають невеликі площі, або вільноплаваючих рослин Lemna minor, L. gibba L., Spirodela polyrrhiza, Salvinia natans, що вкривають усе плесо. Стариці площею 10-100 га, з товщею води $100-250$ см та мулистими грунтами, заселяють Nymphaea alba L. i Nuphar lutea. Заростання мілководних ділянок цих водойм із товщею води до 100 см відбувається за рахунок Ceratophyllum demersum, Myriophyllum spicatum, Potamogeton perfoliatus i Utricularia vulgaris. У заростанні стариць, які розташовані в південних районах досліджуваного регіону, беруть участь Bolboschoenus maritimus (L.) Palla, Glyceria arundinacea, Typha laxmannii Lepech. i Phragmites australis.

Типова схема заростання заплавних водойм Сiверського Дінця з піщаними та піщано-мулистими грунтами така:

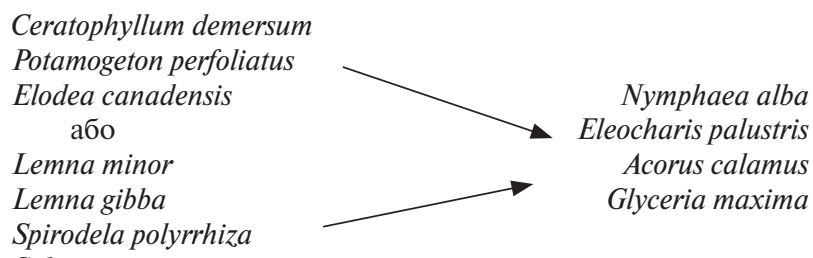

Salvinia natans

Заростання озер Лиманської системи, які розташовані в пониззі другої тераси (першої надлугової) долини Сіверського Дінця, починається з появи вільноплаваючих рослин (Lemna minor, Spirodela polyrrhiza, Salvinia natans, Hydrocharis morsus-ranae) або справжніх водних видів (Potamogeton pectinatus, P. perfoliatus, Ceratophyllum demersum, Myriophyllum verticillatum, M. spicatum, Najas marina). Більшість із цих озер характеризується значними ділянками мілководь (до $80 \%$ від площі водойми) з товщею води до 200 см, мулистими та піщано-мулистими грунтами, які за 2-3 роки повністю заростають угрупованнями справжніх водних рослин. Процес заростання повітряно-водними рослинами починається з появи куртин повітряно-водних рослин Scirpus lacustris, Bolboschoenus maritimus, Typha angustifolia, T. laxmannii, Phragmites australis і триває кілька десятків років.
Заростання найбільшого озера системи Лиман через перетворення його на став-охолоджувач Зміївської ТЕС має певні особливості. Вони проявляються в заростанні 90 \% площі озера зануреними рослинами - Potamogeton pectinatus, P. perfoliatus, Ceratophyllum demersum, Myriophyllum spicatum, Najas marina. У процесах заростання не беруть участь рослини з плаваючими на поверхні води листками. Повітряно-водними рослинами (Phragmites australis, Typha angustifolia, Scirpus lacustris, Bolboschoenus maritimus) заростає $10 \%$ площі (прибережні ділянки південно-східної частини озера). Це, ймовірно, обумовлено значною площею та невеликою глибиною водойми, що спричиняє хвилювання водної поверхні, яке перешкоджає заростанню видами з плаваючими листками та уповільнює процес заселення повітряно-водною рослинністю прибережних ділянок. Через скидання теплових вод електростанції заростання північно-західної частини озера відбувається за участю Vallisneria spiralis, Elodea canadensis i Potamogeton trichoides. Процеси заростання озера пришвидшені (2-3 роки), оскільки частина водойми не замерзає взимку, що сприяє вегетації занурених рослин протягом року.

Процес заселення мілководних озер борової тераси з товщею води до 100 см потужними мулистими та торф'янистими грунтами відбувається за участю справжніх водних рослин - Ceratophyllum demersum, Utricularia minor L., Hydrocharis morsusranae, Nuphar lutea та повітряно-водних видів Sagittaria sagittifolia, Glyceria maxima, Typha angustifolia i Phragmites australis.

Процес заростання солонуватоводних водойм третьої тераси Сіверського Дінця (урочище «Горіла долина»; Зміївський р-н, Харківська обл.) починається з появи справжніх водних рослин Batrachium rionii (Lagger) Nym., B. trichophyllum (Chaix) F.W. Schultz, Ceratophyllum demersum, які за 2-3 роки займають майже всю площу водойми (оз. Горіле). Більшість мілководних озер (глибина 0-50 см) заселяються повітряно-водними рослинами, серед яких спочатку з'являються Mentha aquatica, Butomus umbellatus L., Scirpus lacustris, S. tabernaemontani C.C. Gmel., Eleocharis palustris, E. uniglumis (Link) Schult. На 3-4-й рік у процесі заростання беруть участь Bolboschoenus maritimus var. compactus, Typha laxmannii, T. angustifolia та Phragmites australis. 
Узагальнююча схема заростання озер із пішаними та піщано-мулистими грунтами така:

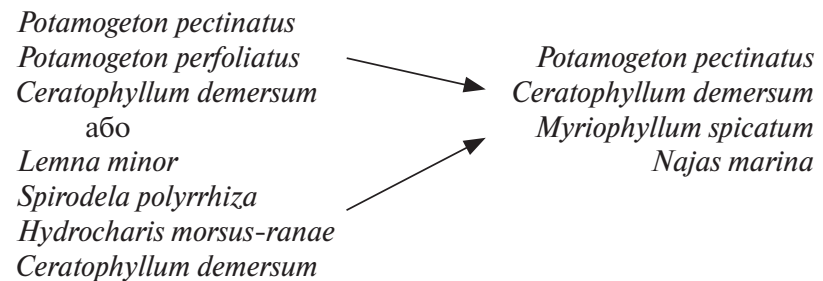

Для озер iз потужними мулистими та торф’янистими грунтами:

Lemna minor

Spirodela polyrrhiza

Salvinia natans

Hydrocharis morsus-ranae

Ceratophyllum demersum

$\longrightarrow \begin{array}{r}\text { Hydrocharis morsus-ranae } \\ \text { Utricularia minor } \\ \text { Nuphar lutea } \\ \text { Sagittaria sagittifolia } \\ \text { Glyceria maxima }\end{array}$

Для досліджуваної території досить характерні сингенетичні зміни на новостворених екотопах штучного походження. Найбільш виражені вони у водоймах зі штучно регульованим гідрологічним режимом (ставах, водосховищах). Водосховища досліджуваного регіону долинного типу, з невеликими площами мілководдя та значно трансформованими прибережними територіями (Бєлгородське й Печенізьке). Вони належать до слабозарослих (10\%). Характер заростання водосховищ залежить від глибини, водного режиму, рельєфу дна та ступеня трансформації прибережних територій [3]. Характер і темпи заростання окремих ділянок водосховищ різняться. Заростання мілководдя починається з одновидових угруповань Glyceria fluitans (L.) R. Br., Butomus umbellatus, Sagittaria sagittifolia, Typha angustifolia, Phragmites australis. Найбільші ділянки заростання (понад 50 \% від загальної площі) займають угруповання Typhetum angustifoliae Pignatti 1953 та Phragmitetum communis (Gams 1927) Schmale 1939. Протягом 3 -х років на відкритій літоралі вони формують прибережні смуги на захищених ділянках мілководь - куртини з подальшим мозаїчним типом заростання. На ділянках із товщею води 50100 см з'являються окремі куртини справжніх водних рослин - Potamogeton perfoliatus, P. pectinatus, Ceratophyllum demersum, Najas marina, які протягом 3-4 років покривають відкриті мілководні ділянки літоралі. Заростання мілководь, розташованих у зоні гирлових ділянок приток, відбувається за участю Ceratophyllum demersum, Nuphar lutea та Nymphaea alba, які за 3-4 роки збільшують свої площі, з повітряно-водних рослин спостерігаються лише куртини Sagittaria sagittifolia та Scirpus lacustris
(Печенізьке водосховище, Вовчанський і Печенізький райони Харківської обл.).

Захищені ділянки мілководь із товщею води до 50 см заростають такими повітряно-водними рослинами, як Alisma plantago-aquatica, A. lanceolatum With., Acorus calamus, Eleocharis palustris, котрі через 2-3 роки витісняються Glyceria maxima, G. fluitans, Typha angustifolia, Phragmites australis. На захищених мілководдях і в затоках із товщею води 50150 см з'являються Potamogeton lucens L., Caulinia minor (All.) Coss. et Germ., Persicaria amphibia (L.) Delarbre, Nuphar lutea, Nymphaea alba. На 4-5-й рік заростання на таких ділянках переважають повітряно-водні види Typha angustifolia та Phragmites australis.

Узагальнена схема заростання ділянок водосховищ має такий вигляд:

Ceratophyllum demersum

Potamogeton perfoliatus

Potamogeton pectinatus

Ceratophyllum demersum
Potamogeton lucens
Najas marina
Nuphar lutea

Caulinia minor Nuphar lutea

Процес заростання ставків відбувається досить швидко (упродовж 3-5 років), що обумовлено невеликою їх глибиною по всій площі водойми. Сингенетичні зміни ВВР функціонуючих ставків відрізняються від залишених. На початкових етапах функціонуючі ставки заростають вільноплаваючими рослинами Lemna minor, L. trisulca, Spirodela polyrrhiza, Hydrocharis morsus-ranae. Далі, на 2-3 рік, з'являються одночасно повітряно-водні та справжні водні рослини. Прибережні ділянки заростають куртинами Glyceria fluitans, Eleocharis palustris, Bolboschoenus maritimus, Scirpus lacustris, Typha latifolia і Phragmites australis. На мілководді 3 товщею води 20-50 см оселяються Ceratophyllum demersum, Potamogeton natans і P. crispus L., які за 1-2 роки займають майже всю площу водойми. Розвиток ВВР до стадії формування повноцінних угруповань і поясів відбувається рідко, оскільки внаслідок спускання води або чищення водойми розвиваються піонерні угруповання. Результатом є поява мозаїчних ценозів, утворених водними та повітряно-водними видами. Піонерами заростання в залишених ставках є Lemna minor, L. trisulca, Spirodela polyrrhiza, Hydrocharis morsusranae, Ceratophyllum demersum, котрі за 2-3 роки покривають усю водойму. На прибережних мілководних ділянках формуються куртини Butomus umbellatus, Sagittaria sagittifolia, Oenanthe aquatica, Typha angustifolia, Phragmites australis. На 4-5-й рік 
80 \% прибережних ділянок із товщею води до 50 см заростає Typha angustifolia та Phragmites australis. Ділянки з мулистими грунтами й товщею води 0-20 см заселяють Bidens cernua L., B. frondosa L., Persicaria hydropiper, Lycopus europaeus L. Ступінь заростання ставків досліджуваної території коливається в межах 5-90\%.

Типова схема заростання ставків досліджуваного регіону така:

Lemna minor

Lemna trisulca

Spirodela polyrrhiza

Hydrocharis

morsus-ranae де відбувається відновлення вихідної рослинності на порушених екотопах унаслідок спуску води, викошування та намивання грунту. Відновлювальні сингенетичні зміни ВВР властиві переважно ставкам; спостерігаються вони також на прибережних ділянках гирлової частини русла Сіверського Дінця. Провідними факторами цих процесів на відзначених ділянках є гідрорежим та інтенсивність формування екотопів [4]. Ці зміни охоплюють стадії утворення несформованих угруповань, формування монодомінантних ценозів і угруповань, які відповідають екологічним умовам місцезростань [5].

Відновлення ВВР після спуску води в ставках починається із заростання повітряно-водними рослинами - Alisma plantago-aquatica, Ranunculus sceleratus L., Alopecurus geniculatus, участь яких різко зменшується вже на другий рік. У подальшому, на 2-3-й рік, у процесі відновлення ВВР на обводнених ділянках із товщею води 20-50 см формуються монодомінантні ценози з Ceratophyllum demersum, Potamogeton natans, P. crispus, якими через 1 рік заростає $80 \%$ площі водойми. На прибережних ділянках ставків у заростанні беруть участь такі повітряно-водні види, як Glyceria fluitans, Eleocharis palustris, Bolboschoenus maritimus, Scirpus lacustris, Typha latifolia, Phragmites australis, котрі формують окремі куртини. Відновлення ВВР після викошування відбувається двома шляхами. У першому випадку, після часткового вилучення рослинної маси, процес відновлення перебігає досить швидко (3-5 років). При цьому спочатку поновлюються ценози повітряно-водних рослин (Typha latifolia, T. angustifolia, Phragmites australis), потім - ценози, сформовані вільноплаваючими та зануреними рослинами (Lemna minor, Spirodela polyrrhiza,
Ceratophyllum demersum, Potamogeton perfoliatus, P. natans, Myriophyllum spicatum). Такі зміни характерні здебільшого для ставків. У другому випадку, в разі повного знищення ВВР унаслідок днопоглиблювальних робіт, спочатку формуються піонерні ценози з Alisma plantago-aquatica, Oenanthe aquatica, Butomus umbellatus, Alopecurus geniculatus, а згодом (через 5-7 років) - мозаїчно розташовані зарості повітряно-водних і занурених рослин (Phragmites australis, Typha angustifolia, Ceratophyllum demersum, Najas marina). Ці зміни спостерігалися на ділянках русла Сіверського Дінця в нижній течії (Усть-Донецький р-н, Ростовська обл., Росія). Заростання ділянок русла річки біля місць скидання та потрапляння стоків промислових об'єктів відбувається лише до стадії формування мозаїчно розміщених заростей повітряно-водних рослин широкої екологічної амплітуди (міста Лисичанськ i Рубіжне, Луганська обл.). Вторинний сингенез унаслідок намивання грунту починається 3 появи окремих екземплярів Potamogeton perfoliatus i P. compressus, якими заростає мілководдя з товщею води до 50 см і піщаним грунтом. Одночасно прибережні ділянки завглибшки 0-20 см заселяють Phragmites australis, Echinochloa crusgalli (L.) P. Beauv. та Amorpha fruticosa L. (хутір Костіно-Горський, Константинівський р-н, Ростовська обл., Росія). За 3-5(7) років вторинний сингенез змінюється ендоекогенезом.

\section{Висновки}

У результаті здійсненого аналізу заростання водойм долини р. Сіверський Донець з'ясовано, шо розміри площ, на яких відбуваються сингенетичні зміни, незначні та охоплюють близько $10 \%$ території, зайнятої ВВР. Вони приурочені переважно до мілководь новостворених ставків і мілководних захищених ділянок непроточних водойм, русла річки, каналів, які перебувають на початкових стадіях заростання. Найбільшими площами заростання вирізняються ділянки русла у верхів'ї Сіверського Дінця, гирлові ділянки основних приток, каналів із піщано-мулистими грунтами, заплавних водойм із мулистими грунтами, верхів'я водосховищ.

Тривалість сингенетичних змін залежить від типу водного об'єкта. Найшвидше (за 2-5 років) вони відбуваються в непроточних мілководних, захищених від вітру та хвиль, водоймах (заплавні водойми, ставки), найдовше (декілька десятків років) - у водоймах із незначними площами міл- 
ководь і трансформованими прибережними територіями (водосховища), на ділянках русла зі значною течією, крутими берегами, а отже, - стрімким збільшенням водної товщі, переважно з піщаними грунтами (середня та нижня течії Сіверського Дінця). У процесі сингенезу першими поселяються види-піонери, серед яких значна кількість однодольних. Ці види переважно анемохорні, мають широку екологічну амплітуду. В подальшому з'являються гідро- та зоохорні види, оскільки на перенесення їхніх діаспор потрібно більше часу.

На природне заростання водойм досліджуваного регіону значно впливають антропогенні фактори, які вносять істотні зміни в розвиток цих процесів. Серед них провідними є створення штучних водойм, вплив на характер водотоку (гідроспоруди, днопоглиблювальні роботи), зміни в гідрорежимі штучних водойм, скидання стічних вод підприємствами і ТЕС, вилучення рослинної маси з водойм, намивання грунту. 3'ясовано, що у зв'язку зі збільшенням антропогенно-трансформованих територій і слабкістю ценотичних зв'язків між рослинами на цих ділянках активну участь у заростанні беруть адвентивні види з широкою екологічною амплітудою (Elodea canadensis, Vallisneria spiralis, Caulinia flexilis Willd., Pistia stratiotes), які витісняють із ценозів рідкісні види.

\section{СПИСОК ЛІТЕРАТУРИ}

1. Александрова В.Д. Динамика растительного покрова // Полевая геоботаника. - М. - Л.: Наука, 1964. - Т. 3. C. $300-450$.

2. Алексеенко М.И. Растительные ресурсы озер Змиевского района Харьковской области // Тр. н.-и. Ин-та биол. и биол. ф-та ХГУ. - 1956. - Т. 25. - С. 219-229;

3. Дубина Д.В. Вища водна рослинність (Рослинність України) / Відп. ред. Ю.Р. Шеляг-Сосонко - К.: Фітосоціоцентр, 2006. - 534 с.

4. Дубина Д.В., Шеляг-Сосонко Ю.Р., Жмуд О.І., Жмуд М.С., Дворецький Т.В., Дзюба Т.П., Тимошенко П.А. Дунайський біосферний заповідник. Рослинний світ. К.: Фітосоціоцентр, 2003. - 459 с.

5. Жмуд О.І. Сингенетичні зміни рослинності Дунайського біосферного заповідника // Укр. ботан. журн. - 2000. 57, № 3. - С. 272-277;

6. Лавренко Е.М. Бореальная растительность Лиманской группы болот и озер в долине среднего Донца // Проблемы биогеоценол., геоботан. и ботан. географии. - Л.: Наука, 1973. - С. 125-155.

7. Шенников А.П. Введение в геоботанику. - Л.: Изд-во Ленинград. ун-та, 1964. - С. 324-327.

Рекомендує до друку

Надійшла 23. 09. 2013 p.

Я.П. Дідух

\section{А.О. Казаринова}

Институт ботаники имени Н.Г. Холодного НАН Украины, г. Киев

Харьковский национальный университет имени

В.Н. Каразина, Украина

\section{СИНГЕНЕТИЧЕСКИЕ ИЗМЕНЕНИЯ ВЫСШЕЙ ВОДНОЙ РАСТИТЕЛЬНОСТИ ДОЛИНЫ p. СЕВЕРСКИЙ ДОНЕЦ}

В статье изложены результаты исследований сингенетических изменений высшей водной растительности долины Северского Донца, которые проводились на протяжении 2011-2012 гг. Проанализированы основные направления зарастания разных типов водоемов исследуемой территории. Установлены особенности протекания изменений в зависимости от типа водоема, глубины, характера субстрата и антропогенного влияния.

Ключевые слова: высшая водная растительность, динамика, сингенез, сукцессионные ряды, Северский Донец.

\section{G.O. Kazarinova}

M.G. Kholodny Institute of Botany, National Academy of Sciences of Ukraine, Kyiv

V.N. Karazin Kharkiv National University, Ukraine

\section{SYNGENETIC CHANGES OF HIGHER AQUATIC VEGETATION OF THE SIVERSKY DONETS RIVER VALLEY}

The article presents results of studies of syngenetic changes of the higher aquatic vegetation of reservoirs of the Siversky Donets River valley, which were carried out during 2011-2012. The main directions of overgrowing in different types of reservoirs in the investigated territory have been analyzed. The primary and secondary syngenetic vegetation changes are characterized. Features of the process of changes depending on a reservoir type, its depth, substrate character, and anthropogenic influence, have been established.

Ke y words: higher aquatic vegetation, dynamics, syngenesis, successional series, Seversky Donets. 